\title{
Una cuestión política interna en el reinado de Felipe IV: si las mujeres deben usar velo o no
}

\author{
Javier M. Donézar díez de Ulzzurrun y Laura Santolaya Heredero
}

Escribía cierto autor del siglo xIx al presentar un tratado sobre la decadencia de la seda en España: «Lector, te invito a que no te fijes sólo en lo liviano de este tejido, porque tras él encontrarás muchas consideraciones".

Algo de esto debemos decir al comenzar este artículo sobre la conveniencia o no del uso del velo por las mujeres en la Castilla del siglo XVII. La obra que se pretende analizar o glosar es el tratado de Antonio de León Pinelo, que fue relator del Consejo Real de las Indias, titulado: Velos antiguos y modernos en los rostros de las mujeres. Sus conveniencias y daños. Ilustración de la Real Pragmática de las Tapadas (Madrid, Juan Sánchez, 1641, 137 folios). Tal Pragmática de 1639 prohibía los velos y obligaba a que las mujeres llevaran su rostro descubierto; la cual, por cierto, resultaba ser la cuarta sobre el mismo asunto lo que indicaba que a las precedentes no se les había hecho demasiado caso.

Pero hay que añadir que dicha Pragmática, y lo mismo habían intentado las anteriores, lo que pretendía eliminar no era «el velo en la mujer» sino el velo en general como ocultador de caras que podía inducir a abusos y al desorden. Se indica esto, porque al margen de consideraciones a las que a continuación se hará referencia, resultaba una Pragmática «tanto para mujeres como para hombres". Era el caso de hombres que, vestidos de mujeres y con velo, saldaban sus cuentas asesinando o hiriendo, o que aprovechaban para robar o violar a las mismas mujeres. Utilizaban el velo «para fines ilícitos y escandalosos, fiándose en que cubiertos los rostros no puedan ser conocidos». Pinelo indica que el trueque de vestidos fue siempre algo aceptado, por lo menos implicitamente, por las distintas comunidades. Las mujeres se vestían de hombres para lograr concretos fines y lo mismo podría decirse de los hombres vistiéndose con traje de mujer; a propósito de esto último consideramos obligado decir que mientras las mujeres que vistieron trajes de hombres fueron siempre interpretadas por los lectores de la literatura del Siglo de 
Oro como heroínas, no así los hombres cuyo disfraz venía a mostrar una «extraña actitud» o el paso previo para la comisión de una felonía.

Demuestra con textos Pinelo que lo de vestirse los hombres de mujeres se dio siempre; ya desde los hebreos y luego con los griegos y romanos. $Y$ añade: «Dejo los que se vistieron de mujeres por solo vicio».

Por lo que la Pragmática no sólo se oponía al velo que tapaba los rostros sino que añadía la prohibición de «traer máscaras», para evitar a «los ladrones enmascarados" (hombres, no mujeres), salvo en determinados acontecimientos anuales: las fiestas grandes y extraordinarias (celebraciones de victorias guerreras, matrimonios reales o nacimientos de infantes), las octavas del Santísimo y fiestas del Corpus y Carnestolendas.

Hechas estas primarias observaciones sobre el texto y su Pragmática, vamos a centrarnos en el análisis de las múltiples observaciones que presentaba el moralista Pinelo sobre el uso del velo por las mujeres.

Previamente, habría que preguntar que si el que se siguiera llevando velo, ante la publicada Pragmática que lo prohibía, no era más que la continuación de una «rebelión» por parte de las mujeres que, por este motivo, se había iniciado muchos años antes.

Consideramos que es lícito responder que sí.

La conveniencia de que las mujeres llevaran completamente cubierta la cabeza, por ende el rostro, en la calle e iglesias había sido algo defendido durante siglos por teólogos y moralistas del cristianismo. Lo cual no significa que hubiera sido llevado a la práctica en todos los países europeos al tener muchos de ellos costumbres diferentes; el mismo Pinelo escribía su Tratado para las mujeres de la Corona de Castilla, las que debían cumplir la Pragmática, reconociendo que las de Dinamarca o Flandes siempre habían llevado el rostro descubierto y lo mismo las del Señorío de Vizcaya y Navarra: «En el Señorio de Vizcaya (Vizcaya, Guipúzcoa y Álava) van las mujeres con los rostros descubiertos y lo mismo en Navarra. No así en Castilla y la Corona de Aragón que usan los cubiertos y los tapados». Hay que pensar, también, que en la Castilla de los siglos XVI y XVII eran muchas las mujeres que transitaban por las calles con el rostro descubierto.

La «sutil rebeldía» de las mujeres castellanas comenzó a manifestarse, por lo menos de forma oficial, en los años iniciales del reinado de Felipe II; en 1556 se prohibió a los moriscos, entre otros mandatos, que utilizaran sus trajes. Cierto es que no era la primera vez porque Carlos I en 1526, y a raíz del alzamiento de los moriscos valencianos en la sierra de Espadán, también los había prohibido pero la Pragmática en su día no había entrado en vigor. 
Decimos sutil porque las castellanas, especialmente en las ciudades, se dieron a imitar en lo tocante a la forma de llevar el velo a las moriscas por lo que la misma prenda, que antes era símbolo de honestidad para los moralistas, se convirtió en muestra de deshonestidad. Esto era, si la paternalista tradición judeo-cristiana había impuesto el velo a la mujer durante siglos ahora ésta, y utilizando el mismo velo, había dado la vuelta a la cuestión: empezaba a servirse de él por pura conveniencia, para satisfacción de sí misma. Lo que había sido símbolo de sometimiento al varón, como se verá más adelante, se convertía en bandera de insumisión. Ésta resultaba ser la sutileza. La rebeldía en general, propia de la condición humana ante exigencias que considera no adecuadas, se manifiesta en una negación a lo impuesto: clamaron los gobiernos contra la moda de los vestidos lujosos de mujeres y hombres y ésta, lejos de desaparecer, se fue extendiendo por todas las capas sociales. Clamó la Iglesia en contra de los escotes femeninos y éstos, en vez de reducirse, siguieron aumentando sus límites. Pero la cuestión del velo evidenciaba una rebeldía, pudiera decirse, más "pensada" en tanto seguían las acabadas de citar, más «gruesas» aparentemente; la tradición cristiana lo había siempre defendido y lo había impuesto a la mujer, por lo menos moralmente, para poner de relieve a ella y al hombre cuáles eran sus respectivos lugares en la comunidad. Una rebeldía general hubiera consistido en quitarse los velos cuando la Iglesia solicitaba que las mujeres fueran cubiertas pero no se produjo porque después de haber hecho «de necesidad virtud», proceso más femenino que masculino, éstas empezaban a sentirse cómodas con el velo. De ahí que cuando empezaron a conocerse hechos delictivos, llevados a cabo en su mayor parte por hombres «tapados» y consecuencia de seguir hasta el final los consejos eclesiásticos, los gobiernos optaron por hacer tabla rasa: todo el mundo iría descubierto. En este punto, las mujeres se desmarcaron optando por seguir con el velo; llegaba el resarcimiento después de tanto tiempo y la contestación fue, más o menos, algo parecido a «si no quieres taza, taza y media».

El asunto, en principio, no fue motivo de excesiva preocupación para confesores, predicadores y demás varones guardianes de las costumbres $y$, de hecho, sobre él se escribió muy poco, quizás porque la transgresión «real» a la Pragmática no parecía ser una transgresión «moral»; en definitiva, el uso del velo en sí se había mostrado a lo largo del tiempo como beneficioso. El mismo Pinelo en su introducción avisaba al lector que todavía no se había escrito nada sobre la cuestión (año 1641), y que solamente lo había hecho fray Nicolás Aurífero, carmelita, «hacía ya más de cuarenta años» con una obra titulada De Velamine mulierum, pero como no alcanzó a imprimirla «sólo nos dejó la noticia y el deseo de verla». 
Pero la transgresión «real» a las sucesivas Pragmáticas comenzó a inquietar a los mencionados guardianes a medida que fue descubriéndose la, hasta entonces silenciosa y encubierta, transgresión «moral». Las mujeres, precisamente las veladas, gozaban de más libertad personal. $Y$ Pinelo, cual moralista-detective engañado en primera instancia, acabó cayendo en la cuenta y se dio a elaborar una distinción que, en un primer momento, podía salvarle y podía salvar su Tratado: la clave estaba en cómo aquellas se ponian el velo. Y distinguió entre mujeres cubiertas y tapadas; las primeras utilizaban el velo para cubrirse toda la cabeza, rostro incluido, lo cual estaba en total consonancia con la tradición cristiana al respecto. Las segundas, imitando a las moriscas, con el velo tapaban tan sólo una parte de la cara dejando descubierto el ojo izquierdo: éste era el aspecto deshonesto de la cuestión. Por lo que acabó concluyendo, como se indicará, que mientras la Pragmática de 1639 prohibía este segundo procedimiento, dejaba en libertad a las que se sirviesen del primero lo cual no respondia en absoluto a la intención del legislador. Para éste, como se ha indicado, primaba ante todo el orden público y el interés por evitar que personas, aprovechando el ir veladas, cometieran altercados y desórdenes; como el velo lo llevaban las mujeres - por lo menos en teoría- de ahí su exigencia de que todas fueran descubiertas.

Con respecto a la Pragmática de Felipe II, Pinelo escribía:

"Y aunque los moriscos lo sintieron de modo que de ello tomaron motivo para su mayor rebelión, al fin, las mujeres que eran las que más lo usaban, dejaron el traje árabe y vistieron basquiñas, mantos y sombreros, y desde entonces comenzaron a taparse con los mantos castellanos como antes se tapaban con sus sindones o lienzos árabes» 1.

El vestido que la mujer morisca hubo de abandonar había sido descrito así por Jerónimo Münzer a su paso por Granada:

"Las mujeres usan calzas de lino o de lana ancha y con pliegues, como las de los monjes, que se atan más abajo de la cintura, cerca del ombligo; sobre ellas, pónense una camisa larga de lino y encima una túnica de lana o de seda, según la hacienda de cada cual. Cuando salen de casa van cubiertas con una tela blanquísima de lino, algodón o seda, tapándose la cabeza y cara de modo que no se les ven más que los ojos".

\footnotetext{
1 LEÓN F'INELO, ANTONIO dE: Velos antiguos y modernos en los rostros de las mujeres. Sus conveniencias y daños. Ilustración de la Real Pragmática de las Tapadas. Madrid, Juan Sánchez, 1641,137 fols.
} 
Pero mientras las moriscas hubieron de adaptarse a una forma nueva de vestir, la castellana, se resistieron a abandonar la tradición de taparse el rostro aunque fuera con nuevos tejidos.

"Y como es uso garboso, lascivo, alegre y, como decimos, de garabato, y las moriscas, por ser todas de excelentes ojos, andaban así más briosas y apuestas que las españolas, y éstas habían comenzado, ya desde antes del año de 1566 a agradarse del tapado y a usarle también, confundiéndose por este modo las unas y las otras, llegó a introducirse del todo por éste de sesenta y seis o sesenta y siete, y fue con tanto exceso que veinte años después, en las Cortes de Madrid de 1586, se trató su prohibición, que se promulgó la vez primera por ley el de noventa, y después otras tres, hasta la última que vamos ilustrando»?

En estas Cortes de 1586 se aportaron dos principales razones en contra del uso de los velos: la primera, que los hombres al acercarse intencionadamente a las mujeres en la calle "se confundían", lo cual estaba provocando "grandes ofensas a Dios»; esto era que, pretendiendo satisfacer sus deseos con una mujer, podian encontrarse con que ésta era su esposa, su hija o su hermana. Dicha masculina razón reflejaba bien a las claras la cotidiana realidad de la sociedad de finales del XVI. La segunda razón también tenía a los hombres como únicos sujetos activos y era prolongación de la primera: éstos, en sus particulares acercamientos, también podían confundirse en lo referente a la clase social de las mujeres. A las mujeres, de forma directa, las Cortes dedicaban un especial juicio señalando que el ir tapadas les daba libertad y la posibilidad de encontrar a su antojo el tiempo y el lugar para las citas, lo que implicaba decir que las culpables de lo que estaba sucediendo eran ellas. Por nuestra parte hemos de decir que es de suponer que «hubiera de todo", máxime atendiendo a la rebeldía femenina que venimos intentando poner de relieve.

Transcribimos el texto por su interés:

"Ha venido a tal extremo el uso de andar tapadas las mujeres que de ello han resultado grandes ofensas de Dios, un notable daño de la República, a causa de que en aquella forma no conoce el padre a la hija, ni el marido a la mujer, ni el hermano a la hermana; y tienen la libertad, tiempo y lugar a su voluntad; $y$ dando ocasión a que los hombres se atrevan a la hija o mujer del más principal, como a la del más vil y bajo, lo que no sería si diesen lugar yendo descubiertas a que la luz discerniese las unas de las otras, porque entonces cada una presumiría ser y sería de todos diferentemente tratada, y que se viesen diferentes obras en las unas y en las otras ${ }^{3}$.

Ibidem., id.

PINELO, op. cit., fol. $82 \mathrm{~V}$. 
Finalmente, se indicaba que llevando los rostros descubiertos se evitarían también los grandes males que provenían de los hombres vestidos como mujeres. La multa que se imponía a las tapadas/os era de 3.000 maravedís.

Pasaron más de cincuenta años y las mujeres seguían haciendo caso omiso a las sucesivas Pragmáticas. La rebeldía femenina resultaba ya prolongada y los motivos para suprimir los velos continuaban siendo los mismos. Pinelo al justificar la Pragmática de 1639, motivo de su Tratado como se ha indicado, veía estos inconvenientes al uso del velo:

1. «De que resulta no sólo la osadía en ellas sino el exponerse a que les suceda con sus propios deudos algún desastre irreparable».

2. «Es la ocasión y tiempo que el tapado da a las mujeres para salir cuando y adonde quieren, sólo fiadas de que no son conocidas".

3. «La contingencia a que se exponen las tapadas de que les pierdan el respeto los hombres, y aun las mismas mujeres, por no conocerlas, y hallarse en ellas lo que ponderó Tertuliano, que no se diferencian en el traje las buenas de las malas (...) Con que se persuade cada uno que puede llegar libremente a hablar, y aun a manosear a cualquiera, que a estar descubierta no osara".

4. «Atreverse hombres vestidos de mujeres, fiados en el tapado, a cometer delitos y sacrilegios".

5. «Es el invencible». "Se reconoce que debe ser muy evidente daño pues insta tanto al remedio" ${ }^{4}$.

Pinelo, con estos puntos, no hacía más que resumir el pensamiento oficial (laico y eclesiástico) al respecto. Se indica esto porque siendo defensor acérrimo de la mujer cubierta en su totalidad, acabaría convirtiendo su Tratado en un elegante ejercicio de malabarismo escolástico, muy propio de los moralistas de la Contrarreforma, para contentar a todas las partes.

Pero todo tenía su porqué. Tenía que mostrar a la persona que financiaba su libro - una mujer, Dña. María de Avellaneda, condesa de Castrillo- que, al final de todo, lo que había eran mujeres buenas y malas y que el uso o no del velo, ante esta realidad, resultaba secundario; por lo que venía a insinuar a la condesa que, pese a la normativa exigida en la Pragmática, podría utilizar el velo según su conciencia y conveniencia particular. Lo mismo que había dado a entender con su distinción entre mujeres cubiertas y tapadas.

Por eso, mientras apoyaba los motivos públicos que habían propiciado la redacción de la Pragmática, se alejaba de ella aportando sus dudas e inconvenientes; y ello después de haber defendido en los 82 primeros folios

4 Pinelo, op. cit., fols. 84-86. 
-de los 137 de que consta el Tratado-, con el Antiguo, Nuevo Testamento y los escritos de los Santos Padres en la mano, la conveniencia, cuasi imperativa, del uso del velo por las mujeres.

La distinción entre mujeres cubiertas y tapadas había resultado un recurso brillante, propio de moralista apreciado, para salir al paso de la Pragmática que mencionaba a «las tapadas» pero no se refería a las «cubiertas". Pero poco importaba al Gobierno tal distinción; ésta era calificada como propia de eclesiásticos. Lo que importaba era lograr que la gente fuera por la calle con el rostro descubierto.

A la altura de 1639, y para empezar, ya no era la cuestión imitar a las moriscas. Se trataba tan sólo del particular proceder de las mujeres castellanas. Por ello, ante la Pragmática aparecida, mostrando una respetuosa aquiescencia, escribía:

«Y aunque se haya admitido en España y estemos por todo lo que de sus velos se refiere, no se puede negar que los tiempos descubren cada día nuevos males, como también nuevos bienes de las cosas; y por esta razón, lo que hoy se permite se podrá prohibir mañana, y al contrario, mandarse 10 que estaba prohibido: porque como siempre los hombres inventan y procuran novedades, a cada una que sale se altera y muda la sujeta materia, y necesita de nueva ley que la disponga (...) Y así, aunque concedamos el uso de los velos en España, con muchos siglos de antigüedad, si ahora sale ley que los prohíbe, y se halla razón que los derogue, contra esta razón y ley no valdrá la costumbre que antes había en contrario.... ${ }^{5}$.

Aceptaba, también y en un acto de sumisión legal, los inconvenientes que podían haberse derivado del uso de los velos:

«En la materia de costumbres, es la experiencia el mejor juez. En lo teórico apenas habrá ninguna que con estudio no se pueda manifestar por muy aparente. Pero en llegando a la práctica, entonces se reconoce todo. Que los velos tengan mucha conveniencia, supuesto que no se niega, no es de importancia que se pruebe. Si pesa más que todas el daño que se sigue de su uso, y éste le atiende la ley Fieal para prohibirlos, sin fruto y sin efecto son las demás consideraciones. $Y$ así se asienta por conclusión llana, y sin controversia en Castilla, que no es conveniente, lícito, ni honesto, que las mujeres traigan velos en los rostros» $\hat{0}$.

Pinelo se rendía, según lo expresado, de modo indirecto - esto es, sin reconocerlo abiertamente- a la imparable rebelión femenina y a la

PINELo, op. cit, fols. $87-88 \mathrm{~V}$.

Pinelo, op. cit., fols. 88 v-89. 
necesidad de acabar con ella. Pero ponía en duda la eficacia de la medida tomada:

"Y la prohibición de los velos, aunque evite algunos inconvenientes, que es muy dudoso, será en cien mujeres que se valían de ellos para lo que no era lícito; pero en recompensa de este útil, expone cien mil que descubre con conocido riesgo de su honestidad".

Además, y a la vista de lo inmediatamente sucedido con la entrada en vigor de la Pragmática (el Tratado está editado en 1641), remachaba:

"no lo afirmo, pero lo advierto por el reparo de algunos que atienden a las acciones y sucesos ordinarios, que nunca se vio la Corte tan llena de muertes violentas, heridas, pendencias, inquietudes y fracasos por mujeres como luego que anduvieron descubiertas. No digo que ésta sería la causa, pero el efecto fue muy notorio, y como no se innovó en otra cosa, hubo quien lo atribuyó a ésta » ${ }^{7}$

Por otro lado, apoyándose en su propio escepticismo sobre el cumplimiento de la Pragmática y estando a favor del uso del velo, aprovechaba la ocasión para alcanzar por lo menos un acuerdo intermedio:

«Pues si es dudoso conseguir el fin que se pretende, en descubrir los rostros de las mujeres, y tan probable el daño que causa, entre aquí la razón que algunos consideran en la ley que es no condenar a las buenas por las malas. (...) Y así, menos escándalo puede causar que ande cubierta la que quisiere, aunque se valgan de esta licencia las malas, que prohibirlo a todas para que comprenda a las buenas: que esto será descubrir un altar para cubrir otro, y aun diciéndolo mejor, descubrir el altar por cubrir lo que no es" 8 .

$Y$ el argumento: si el velo ha sido siempre un «parapeto» (defensa, trinchera) de la mujer honesta, ¿por qué ésta no va a poder seguir utilizándolo si quiere? ${ }^{9}$. Aquí el moralista ya rizaba el rizo en el razonamiento porque defendía que "las honestas" pudieran usar el velo y lo negaba a las «deshonestas». Y en apoyo, el recurso a la distinción entre cubiertas y tapadas: «el cubrirse el rostro es un acto sencillo, que sólo requiere echarse en él un velo simple y suelto, sin más afectación y cuidado que encubrir una imagen para que no sea vista. El taparse no parece que se refiere al velo sino al modo, a la cautela y artificio con que se procura es-

\footnotetext{
Pinelo, op. cit., fols. 105-106.

PINELO, OP. cit., fols. $108 \mathrm{v}-109$.

PINELO, op. cit., fols. $109 \mathrm{v}$.
} 
conder y ocultar el rostro, engañosa y pálidamente. (...) El taparse es embozarse, como decimos, de medio ojo, doblando, torciendo y prendiendo el manto de suerte que descubriendo uno de los ojos, que siempre es el izquierdo, quede lo restante del rostro aún más oculto y disfrazado que si fuera cubierto todo" ${ }^{10}$. Y concluía: "El descubrirse las mujeres los rostros es uso indiferente, el cubrírselos es bueno, el tapárselos es malo porque naturalmente es lascivo» ${ }^{11}$.

Pero Pinelo tenía que salir del embrollo en el que se había metido, porque la Pragmática prohibía a todo el mundo ir cubierto, lo cual no era de su agrado, y debía defender su obediencia.

¿Cómo alguaciles y corchetes iban a saber ante una persona cubierta si era honesta o no a fin de permitirla circular o multarla? En páginas anteriores ya se había guardado previsoramente las espaldas al iniciar que la cuestión de la honestidad o deshonestidad de las mujeres en el fondo no era cuestión de velos sino de la personal intención y esto se reflejaba en los lugares a donde unas y otras acudían. El velo, apuntaba, antes lo llevaban las honestas y deshonestas, pero aquéllas no iban a los lugares de éstas. "La que quiere ser buena mejor ocasión tiene para serlo saliendo cubierta, pues no siendo vista no es deseada ni tan pretendida; y si quiere faltar a sus obligaciones, poco le embaraza el rostro descubierto, pues perdiendo la honestidad en lo más, no es probable que lo excuse en lo menos, antes hallará más ocasiones como queda advertido" ${ }^{12}$.

En el fondo, tanta disquisición dejaba entrever la pugna interna del autor entre aconsejar cumplir la Pragmática y su propio pensar al respecto. Quizás nos hallamos, es una conjetura, ante la respuesta modélica, plasmada en el Tratado, de un consejero contrarreformista - con todos los recursos escolásticos sobre la mesa- a la simple y vital pregunta de su protectora Condesa de Castrillo: «¿Por qué no puedo salir a la calle como quiera sin que nadie me diga nada? ¿Por qué no me puede apetecer un día ir cubierta, o incluso tapada, y otro descubierta?" En definitiva, era la pregunta de todas las mujeres con su consecuente añadido: « ¿Por qué nos tienen que decir cómo debemos ir vestidas por la calle?». La rebeldía resultaba lógica y natural.

Pinelo se quejaba de que otros autores coetáneos no atendieran en sus escritos a esa contestación femenina de seguir sirviéndose del velo a

10 Pinelo, op. cit., fols. 122 v-123.

11 PINELO, op. cit., fols. $124 \mathrm{v}$.

12 PINELO, op. cit., fols. 94 v-95. 
pesar de las reiteradas prohibiciones de las Pragmáticas; venía a indicar tácitamente que no se habían dado cuenta del motivo profundo que conlleva su uso. Y citaba a algunos que, criticando los trajes y los afeites no hacían mención de las mujeres cubiertas y tapadas: Castillo de Bobadilla, Fray Juan de la Cerda que "discurre sobre lo que necesita enmienda en lo tocante a las mujeres", el Maestro Fray Juan Márquez o el también Maestro Bartolomé Jiménez Patón, el Doctor Alonso de Carranza — «el que más empeñó la pluma contra los malos trajes y adornos lascivos», y fue de tal modo que el mismo Pinelo le apodó «la Parca de los trajes», «porque no perdonó a ninguno de cuantos en nuestro tiempo usan las mujeres» 13- o el mismo Doctor Arias Gonzalo que se vio en la obligación de responder a Carranza con el Memorial en defensa de las mujeres de España. Tampoco trataban la cuestión los mismos sermonarios, «que no dejan vicio ni defecto que no reprendan»; «no hay ninguno que culpe ni excluya los velos, ni aun los nombre ni haga mención de ellos, siendo el uso más público, más visto y más notorio que había en Castillas ${ }^{14}$.

El velo, durante siglos, había sido la muestra externa del papel que se pedía a la mujer dentro de la comunidad cristiana. «Jugar» con él o «servirse» de él significaba una general ruptura con dicho orden comunitario. ¿Por qué? Pinelo aportaba las razones del tradicional uso de tal prenda tras anunciar que «sus conveniencias conocieron todos los siglos pasados. Sus daños ha experimentado sólo el presente; parece que más en Castilla que en los otros Reinos de España y aun de Europa, (...) y no es maravilla que veamos aquí prohibido lo que en las diferentes partes se permite y aun se manda» ${ }^{15}$. El velo era símbolo de autoridad, honestidad y sujeción, de ahí que resultara «necesario y loable» que las mujeres «se muestren en público autorizadas a todos, honestas a sí y sujetas a sus maridos y mayores» ${ }^{16}$.

Nos detenemos en recorrer, por separado, los tres conceptos siendo conscientes de que están íntimamente enlazados entre sí y que cada uno precisa del apoyo de los otros.

A) Autoridad. El significado que nuestro autor daba a la palabra, y vaya por delante, no era, siguiendo el actual Diccionario de la Lengua, la de «potestad o facultad», o la de «poder que tiene una persona sobre otra que le esté subordinada» sino su sexta acepción: «crédito y fe que, por su

\footnotetext{
Carranza, Alonso: Discurso contra los trajes y adornos lascivos. Madrid, 1636, 57 fols.

PINELIO, op. cit., fols. 120.

PINELO, op. cit., fols. 1-1 v.

PINELO, op. cit., fol. $10 \mathrm{~V}$.
} 
mérito y fama, se da a una persona o cosa en determinada materia». El velo daba a la mujer el halo de misterio que inducía a la veneración; implicaba, todo a la vez, una barrera, un distanciamiento y una inexactitud; los tres conceptos componían el misterio y éste generaba, por ser misterio, un respeto y una veneración; y favorecía una intangibilidad, algo que no debía ser olvidado en los tiempos que corrían. Proporcionaba, por tanto, autoridad. Era esta idea propia de todas las civilizaciones: los seres, animados o inanimados, cuanto menos vistos serían más respetados y venerados; nadie podía ver al Faraón o al emperador de China. Todas las religiones se apresuraron a rodear a sus dioses de lejanía y misterio -el Supremo no tiene cara- para obtener de los seguidores la fe ("creer en lo que no vimos») y luego, por ella, la pertinente obediencia a los que se mostraban como interlocutores de aquéllos.

En la religión judaica, Yavé dirigió al pueblo de Israel por medio de elegidos interlocutores y manifestó su poder a través de señales físicas pero permaneció invisible para el conjunto del pueblo; el Arca de la Alianza, lugar donde reposaba su aliento y fuerza, estaba compuesta por varias arcas interpuestas, de menor a mayor, y toda ella estaba cubierta con siete velos. La religión cristiana, heredera y distinta de la judaica, siguió los procedimientos; no trataba de ocultar a Yavé sino a Jesucristo, su Hijo. Los llamados sagrarios, ornacinas con llave a semejanza del Arca de la Alianza, encerraban la materia que era su Cuerpo y un velo se extendía por encima de ellos. $Y$ bajaban y subían, a conveniencia de sus representantes, los velos sobre las custodias. Y en los días de viático para los enfermos, el sacerdote portaba el sacramento por la calle cubierto con un velo. En la misa hasta después del ofertorio no se quitaba el tejido brocado que cubría el cáliz y la patena con la hostia. Y en las procesiones del Santísimo el día del Corpus los toldos por las calles de la ciudad eran la réplica a los velos del sagrario. Luego, este distanciamiento-veneración, aplicado al Cuerpo de Jesucristo, sus representantes, y por conveniencia, lo prorrogaron a las imágenes de la Virgen y los santos.

Trento habia declarado la necesidad de imponer el «distanciamiento" en todos los campos (teología, filosofía, moral y derecho) para acabar con la "cercana naturalidad" del Renacimiento como único modo de rehacer la corrompida sociedad cristiana. Las razones de que se sirvió - «tan brillantes meditaciones confundían a reyes", según expresaba un teólogofueron tan diversas y proyectadas tan a largo plazo que lograron llegar hasta entrado el siglo $\mathrm{XX}$.

En el tiempo que nos ocupa, el sombrío Barroco, era preciso a corto plazo cubrir esculturas y pinturas antiguas para no provocar, trazar nuevos 
cánones para los artistas y, sobre todo, alejar de la vista del pueblo todo lo sacral; se debía evitar lo tangible - lo tocable-. Estamos convencidos de que para Trento el sentido corporal que debía ser reducido, y a poder ser eliminado, era el tacto más que la vista, aunque ésta llevara a aquél; con el tacto sobraba la fe y la esperanza, dos principales virtudes teologales que hallaban su justificación precisamente en la distancia.

De acuerdo con lo acabado de indicar, Pinelo escribía que el velo servía en la Iglesia para guardar «las cosas de más estimación» y así se aplicó a los rostros de las mujeres: "pues son imágenes del honor, y vasos de tanto precio como fragilidad; que parece se la dio tan grande la naturaleza para incitar más nuestro cuidado a defenderlas, y nuestra atención a guardarlas, estimarlas y autorizarlas". Hay que indicar, a propósito, que el símil del vaso, del recipiente 0 , incluso, del cáliz aplicado a la mujer era muy empleado en los textos de moralistas y teólogos de entonces con todas sus tácitas connotaciones.

"Y siendo como es el santuario matrimonial, ara de la voluntad de su esposo, altar de su afición, pintura de sumo valor y de mayor peligro, échensela cortinas, y procúrese sustentar sin mácula vaso tan precioso y delicado, que con el menor golpe se quiebra, y con el átomo más invisible se mancha y desluce» ${ }^{17}$. La frase no ofrece desperdicio para la glosa: que la mujer fuera vista por todos, sin velo, acarreaba peligro por lo que "échensela cortinas". Aquí ya se dejaba de lado la relación velo-autoridad y se entraba en la de no velo-peligro para el esposo, por lo que recordaba que aquélla era ara de la voluntad y de la afición de éste y que, como sacerdote del santuario, solamente él tenía el poder de cubrirla y descubrirla según su conveniencia y el de "sustentar sin mácula vaso tan precioso».

Precisado esto, retomaba Pinelo la relación velo-autoridad. Comparaba a la mujer con las imágenes a las que se tiene mucha devoción y traía el ejemplo de un crucifijo, que estaba en el convento de San Andrés de Medina del Campo, al que «le quitaron las cortinas, con que le tenían cubierto con tres velos, que estas representaciones ayudan mucho a la reverencia y veneración; con esto ha cesado el fervor y buena parte de la devoción del pueblo». Y lo mismo sucedía con el velo de las religiosas; al respecto, traía lo que dijo Fray Juan de la Cerda a una que profesaba, comparándola con los retablos e imágenes: "así como a los retablos nuevamente asentados en la iglesia, los suelen cubrir con guardapolvo y a las imágenes con velo; para que así quedéis señalada como Esposa de

17 Pinelo, op. cit., fols. 12-13. 
Una cuestión política interna en el reinado de Felipe IV: si las mujeres deben...

Jesucristo; y como un retablo nuevamente asentado en la Religión, para que con el velo sus ricas pinturas conserven sus lustres y colores".

B) Honestidad. Partiendo de la base de que la honestidad, por principio, era propia de hombres y de mujeres, Pinelo añadía:

«es más propia de las mujeres; pero en ellas tan delicada, tan peligrosa que con un descuido se ofende y con una liviandad se pierde. Con que para conservarla pura y entera es necesario que se ayude de cuantas circunstancias o accidentes fuere posible; y siendo símbolo suyo el velo en el rostro, conveniente parece que le usen las mujeres» ${ }^{18}$.

La honestidad era latiguillo permanente en boca y escritos de los conductores de la España Barroca. Era referencia obligada en el momento de enderezar supuestos torcidos caminos de actitudes sociales. Pero mientras el concepto hoy hace principal referencia a una postura de conciencia, por tanto a algo interno, que en un segundo momento se manifiesta en la sociedad con acciones a favor de ésta («honestidad con uno mismo y con los demás»), en el siglo xvil prevalecía la atención a una actitud externa determinada que daba por supuesto algo interior -la conciencia- y también su posterior reflejo en acciones convenientes para los demás. Con una particularidad consecuente que quien precisaba si la actitud externa era correcta era la sociedad 0 , de modo más concreto, los "conductores" de la misma.

Volviendo a tomar el Diccionario de la Lengua, éste en su descripción de «honestidad» incide más en la actitud externa que en la interna: "Compostura, decencia y moderación en la persona, acciones y palabras". Actitud que hace referencia a la mesura. Tomados por separado los conceptos que describen la honestidad, se tiene que compostura es «modestia, mesura», decencia es "recato, honestidad, modestia» y moderación es "cordura, sensatez, templanza en palabra y acciones". Todo es dar vueltas a lo mismo sin precisar demasiado. Baste observar que decencia que explica honestidad, a su vez es explicada por ésta o que modestia está presente en la descripción de compostura y decencia. ¿Por qué señalamos esto? Para poner de relieve la dificultad de precisar "honestidad».

La palabra es etérea, poco precisa y, a nuestro juicio, descrita así a propósito; aquí está la clave del asunto porque cuando algo que se define de forma buscadamente confusa, con el pretexto de que sea válido para siempre, pretende implantarse como norma a seguir por una determinada

18 PINELO, op. cit., fol. $14 \mathrm{v}$. 
sociedad, siempre será preciso alguien que, en los diversos tiempos, lo explique y traduzca para que pueda ser obedecido. $Y$ el hecho de explicar, precisamente, es el que otorga poder a ese alguien. $Y$ volvemos a hacer referencia a los conductores de la sociedad, los que se encargaban de dar la explicación conveniente a sus propios intereses o a los intereses de aquellos a quienes servían; son los que diciendo qué debía entenderse por "compostura, decencia o moderación» en cada situación, aseguraban su particular poder.

Si en el XVII la honestidad era sobre todo una actitud externa, más propia de mujeres que de hombres, dicha actitud tenía que aparecer en público dotada de unas maneras, de unas formas o de unos trajes. $Y$, de nuevo, el mismo asunto: «alguien» debía señalar cuáles eran acompañándolas con una explicación; y a ello se dedicaron tales conductores, hombres por supuesto, sustentados en los principios de la religión católica.

No puede olvidarse que si la honestidad es algo propio de la persona, Trento la convirtió en algo externo, que fuera mostrada "afuera» -el Catecismo Romano es un relevante ejemplo- para proteger a su mundo masculino del pecado. Con esto Trento y su Contrarreforma no hacían más que evidenciar un feroz pesimismo sobre las relaciones de los hombres con las mujeres; éstos, animales en constante celo o perpetuos violadores in pectore, según, precisaban para salvarse no ver a las mujeres, que éstas fueran recluidas en sus casas o cubiertas por un velo para no fomentar la ocasión del pecado personal o de lucha entre ellos. La honestidad de la mujer guardaba el honor del marido y, al contrario, la deshonestidad de la mujer, concretada en sus maneras de aparecer en sociedad (cabeza descubierta y con adornos o determinados vestidos), era escalón previo para la pérdida del honor de aquél.

El apóstol Pablo en su carta a Timoteo (1 Tim. 2,9) había escrito: "quiero también las mujeres con hábito honesto, con recato y modestia, sin rizado de cabellos, ni oro, ni perlas, ni vestidos costosos, sino con obras buenas, cual conviene a mujeres que hacen profesión de piedad»; y ello porque, como señalaba el Catecismo de Trento, los ojos son «focos que encienden en el corazón la sensualidad» de los hombres, y la experiencia confirmaba que muchas caídas habían tenido su origen en miradas lascivas teniendo como incentivo «la moda deshonesta» (de las mujeres).

Mucho podría escribirse sobre las distintas manifestaciones que los contrarreformistas exigían a la mujer para que ésta demostrara su honestidad (no siendo pequeña la «del cuidado de la casa como obligación y el estudio como diversión»), pero han sido expuestas en otras investigaciones en estos últimos años y quedarían fuera de la pretensión de este artículo. 
Para el mundo barroco que estamos tratando, el modelo de mujer honesta, como se sabe, era la Virgen María. Pero era descrita de tal forma por teólogos y místicos que imitarla se convertía en algo inalcanzable; por de pronto no necesitaba ir con el rostro cubierto, sino al contrario. El franciscano fray Melchor de Cetina en su Exhortación a la devoción de la Virgen (1618), no tenía reparo alguno en describirla así, reafirmando lo que había dicho Nicéforo:

«El color del rostro era trigueño; el cabello rubio; ojos verdes y agudos; las cejas, negras y arqueadas; la nariz, proporcionada; los labios, rosados y adornados de gran suavidad en el hablar; el rostro, más largo que redondo; las manos y dedos, largos en debida proporción. Su vestido era honesto y Ilano, sin ninguna blandura ni curiosidad; su trato, humilde y sin altivez».

Y añadía:

«era su rara hermosura, acompañada de una modestia y honestidad tan singular, causada de la hermosura y santidad de su alma, que ninguno la miró ni puso en ella los ojos que no le reprimiese las pasiones de la hurnana fragilidad y le moviese a pensamientos castos y honestos".

Tal y como había escrito el parisense Gersón: «La fisonomía del rostro de la Virgen movía a los que la miraban a toda castidad y mortificaba en ellos los pensamientos deshonestos»; y por si fuera esto poco, Joan Mayor declaraba: «Firmemente creo que el que la miraba, por aquel rato se le apagaba la codicia de la carne (...) De èste privilegio dotó Dios a su Madre: que ningún hombre mortal la codiciase" ${ }^{19}$. Por todo lo dicho, habrá que concluir que ninguna mujer podía seguir los pasos de la Virgen; a lo más, debía limitarse a soñar ser algo parecido. $Y$ en cuanto a los hombres, solamente mirándola se les apagaría «por un rato» su natural codicia de la carne.

Pero es que los místicos tenían buen cuidado de que las mujeres pudieran pretender imitar a la Virgen; como que eran flores distintas. «La Virgen, nuestra Señora, fue lilio entre las espinas, porque las demás mujeres hermosas con su hermosura punzan y lastiman a los (hombres) que las miran; pero la Virgen nuestra Señora, como suave azucena, a todos los recreaba y a nadie hirió ni le fue perjudicial...". La hermosura de las mujeres corrientes y normales actúa punzando, envenenando y acaba

19 Cetina, Melchor DE: Exhortación a la devoción de la Virgen. En Místicos Franciscanos españoles, vol. III. Madrid, B.A.C., 1949, págs. 775-776. 
matando: "Es el señuelo con que el demonio suele cazar a los hombres y engañarlos y una trampa que les arma para que tropiecen en ella y despeñarlos en el infierno» ${ }^{20}$. $Y$ como las mujeres no podían ser la Virgen, a causa del pecado original, bueno era que fuesen cubiertas.

Por todo lo indicado hasta aquí, es comprensible que para los contrarreformistas el velo reuniera las precisas cualidades para dotar a las mujeres de honestidad, entendida al modo humano, ya que no podrían lograr, ni rezando en el supuesto de ser hermosas, incitar con la hermosura a los hombres a la castidad.

Para Pinelo dicho velo, además de promover a la honestidad, podría proporcionar hasta un «toque favorecedor». «Viene bien» a las mujeres, escribía, por dos motivos: si el cabello es el velo natural dado para que la mujer se cubra el rostro, «bien se sigue que la misma naturaleza aborrece el vérsele descubierto en público, pues le da con que se oculte y esconda. La segunda, porque si no en todas, en muchas puede ser causa de burla y desprecio". Ya lo dijo Tertuliano: «Dios manda que os cubráis los rostros; creo que esto es porque no se vean los de algunas» ${ }^{21}$. Y de modo "algo más positivo» indicaba que mientras la naturaleza había dado al hombre el cabello para el ornato, a la mujer lo había otorgado «para la decencia», reconociendo que "las hermosea» y, a la vez, ayuda a cubrir el rostro. Si «el velo artificial hace ya las veces del natural, gloria será traerle, injuria será quitarle».

El velo lo debían llevar todas las mujeres: las casadas y las doncellas. $Y$, si se mira bien, especialmente éstas últimas, porque mientras aquéllas debían limitarse a preservar el honor del marido, las doncellas eran, de por sí, «fuente lasciva». Tertuliano afirmaba que Susana se puso el velo, aunque antes andaba sin él, «porque ya temía agradar»; de ahí que, escribía Pinelo, las doncellas fueran con velos, "por ser instrumento de despertar y fomentar el apetito lascivo" $y$, con un toque comprensivo a las costumbres europeas, añadía: «aunque en Flandes no se llevan estos velos porque quieren ostentar la hermosura y adquirir esposos". Por ello, se exponían en esos lugares las mujeres a peligros y engaños, «de que se ven y oyen los muchos naufragios que padecen» ${ }^{22}$. $Y$ de nuevo Tertuliano: "Justamente por no cubrirse el rostro (las doncellas), y gozar de la vanidad de ser solicitadas, necesitan después cubrir los vientres enfermos de su ruina» ${ }^{23}$.

\footnotetext{
CETINA, op. cit., pág. 777.

PINELO, op. cit., fols. $19 \mathrm{v}-20$.

PINelo, op. cit, fol. 32 v.

PINELO, op. cit., fols. $68 \mathrm{v}$.
} 
El velo servía, por añadidura, para muchas cosas además de conllevar la honestidad. Hay que indicar que una practicidad, en la que lo que exige acaba convirtiéndose en útil y beneficioso para el que lo llega a cumplir, era añadida a última hora por los conductores de la sociedad para endulzar y convencer a las renuentes que dudaban cumplir las normas.

El velo daba seguridad a la mujer..., y al marido. Y Pinelo traía ejemplos de lugares musulmanes en los que casadas, solteras y viudas tapaban su rostro: El Cairo, Bagdad, Nubia (allí iban las mujeres desnudas pero ocultaban el rostro), Persia y Turquía. En este último país se exigía, más que en los otros, que las casadas fueran cubiertas:

«Los turcos más que otra gente, procuran y solicitan la honra de sus mujeres. Por eso, las tienen tan reclusas y encerradas en sus casas que apenas ven el sol. Y si alguna ocasión forzosa las obliga a salir fuera, las hacen que salgan tan cubiertas, tan envueltas y tapadas que para los que las encuentran parecen sombras o fantasmas (...). Porque el dejarse ver descubierta la mujer casada, en su casa o fuera de ella, salir a la calle, comprar o vender, es afrenta y aun delito» ${ }^{24}$.

Y añadía Pinelo una serie de particulares consideraciones al respecto que podrían ser resumidas en «los musulmanes saben por qué lo hacen».

Reforzando la idea de que la mujer debía ir cubierta para asegurar el honor del marido, el P. Diego de Celada señalaba que había que «impedir la cruel batería que los jojos de los hombres hacen en la mujer, y los suyos en los de los hombres».

Uno de los principales fines del velo era frenar a los hombres como el torero frena al toro; no podía darse una comparación mejor ni de más raigambre castellano. Se traía a colación la imagen literaria de la mujer «toreando al hombre». "La ferocidad de un toro se quebranta dejándole en los ojos el manto, mientras que el hombre se pone a salvo". En este caso el manto lo dejaba la mujer. "Con la mujer cubierta, ha menester el que va a acometer un tiempo más, que es el que gasta en persuadirla que corra el velo. Es flaca defensa, pero bastarite a veces para que en vencerla se gaste el tiempo y se pase la ocasión". El velo era un manto echado ágilmente a los ojos del hombre ${ }^{25}$.

Pero era preciso que la mujer tuviera voluntad de utilizar el velo para poner freno a los hombres; en la intención se sustentaba buena parte de

\footnotetext{
24 PINELO, op. cit., fols. $36-36 \mathrm{v}$.

25 PINELO, op. cit., fol. 70.
} 
su honestidad. Porque lo propio y natural de los hombres es «que deseen ver el rostro de la mujer sin velo», luego la mujer atenta de ello «mejor irá con velo que sin él». Y lo principal de todo para la mujer y el marido era que nadie se percatara de ella; decía Tucídides «que de la mujer es felicidad que se hable bien, pero mejor que ni bien ni mal»».

Por otra parte, después de lo indicado, resulta claro que las almas de los hombres estaban para los contrarreformistas en constante peligro si los mujeres no usaban el velo; y había que salvarlas. "¿Quién más santo que David? $Y$ de solo ver desde lejos a Bersabé desnuda, sin saberse contener, cometió un adulterio y un homicidio" 26.

La mujer es el peligro del hombre para su salvación. «Hallé —dice el Eclesiastés $(7,27)$ - más amarga que la muerte la mujer, que es lazo de cazadores y una nasa (red redonda y cerrada) su corazón; sus manos, prisiones; el que es sabio huirá de ella, y el necio quedará enredado y su prisionero y puesto del lodo». Pero la Providencia, que es muy sabia, puso en las mujeres la vergüenza y el recato para que se salvaran y... salvaran al hombre: «con esta atención, dice San Juan Clímaco, que fue suma providencia de Dios poner a la procacidad el freno de la vergüenza, porque si le fuera lícito acometer al hombre cuando quisiere, no se salvaría ningunos 27 . Por todo ello, el recato que la naturaleza ha puesto en las mujeres salva a éstas y a los hombres, y con velo más.

«Y así aunque ni el cubrirse ni el descubrirse el rostro la mujer es pecado, por ser acto indiferente, es de los que se califican por los fines; y más probable es que será más ocasionado un rostro descubierto que con velo». Y añadía Pinelo una observación que no tiene desperdicio: «sabemos que incita más un buen rostro que otro que no lo es tanto; y así es resolución, ser menor la culpa con la hermosa que con la fea, como lo insinúa Tertuliano», porque la fea sólo excita a la lascivia y en la hermosa es su hermosura la que conduce a la lascivia ${ }^{28}$.

El velo de las mujeres, por tanto, también colaboraba en la salvación de los hombres clérigos. En la iglesia y durante siglos, escribía nuestro autor, había habido velos entre el pueblo y sus ministros «para dividirlos y separarlos de los seculares; porque no los inquietase la vista de las mujeres, ni pareciese indecente el tenerlas cerca», y de ahí se derivaba «el haberse originado los coros y tribunas aitas, y las rejas y gradas en los presbiterios»

26 PINELO, op. cit., fol. $71 \mathrm{v}$.

27 PINELO, op. cit., fol. 73.

28 PINELO, op. cit., fols. $75-75 \mathrm{v}$. 
y los distintos lugares para hombres y mujeres «dividiéndolos con vallas y canceles y con diversas puertas para entrar..." Y citaba a San Antonino que había contado «la desastrada muerte de un mancebo que contra la orden que había, siempre se pasaba a la parte de las mujeres» 29.

Las mujeres debían ir cubiertas en los templos por la reverencia que se debía a los ángeles, prelados y sacerdotes y porque a éstos "no los inquiete la vista de las mujeres estando sin velos». El sentido de la vista era el que más debían cuidar los eclesiásticos porque era el primer eslabón de una cadena que acababa en la obra; Fray Antonio de Guevara en su Oratorio de religiosos y ejercicio de virtuosos (1542) escribía: «No inmérito dice el santo Job que hizo pacto y conveniencia con sus ojos para que no fuesen en el mirar a mujeres desmandados, porque del mirar viene el hombre a desear, $y$ del desear al pensar, $y$ del pensar a se deleitar, $y$ del se deleitar a se determinar, y del se determinar al pecar, y del pecar a se condenar». Y traía el ejemplo del rey David al que antes hemos hecho referencia: «En el libro de los Reyes, capítulo 11, se dice que de sólo ver el rey David a la hermosa Bersabé, mujer de Urías, que se estaba en una azotea peinando y lavando, se enamoró tan recio de ella, que luego la solicitó y la engañó y con ella adulteró; del cual enorme hecho resultó ella quedar preñada, el marido perder la vida, David macular su fama y escandalizarse toda la república". «Conviene, pues, ante todas cosas, al siervo y aun a la sierva del Señor poner gran recaudo en la vista para que no la traiga derramada, que como el corazón no puede ver, ni saber hablar, ni alcanza a oír, en sólo aquello él piensa de dentro que los ojos le alcahuetean acá de fuera» ${ }^{30}$.

Si la vista parecía ser el general origen de los males en los eclesiásticos, siempre había excepciones y así cuenta Pinelo con respecto al oído y lo peligrosa que podía ser la voz de la mujer: «De la voz, puedo referir de un mancebo que conocí, que habiendo recibido el hábito de una religión estrecha, estando de noche en su celda cuyas ventanas caían a un campo, oyó que una mujer le decía a otra: "Amiga, álzate esas enaguas". Y fue bastante tentación esta voz y el nombre del traje para dejar el hábito y el intento y propósito de ser religioso" " ${ }^{31}$.

C) Sujeción. Era el colofón de las argumentaciones de Pinelo y el que directamente había podido provocar la rebelión de las mujeres. Ir cubiertas por el velo era muestra de sometimiento a los hombres -con él

29 Pinelo, op. cit., fol. 14.

30 Guevara, Fray ANTONIO DE: Oratorio de religiosos y ejercicio de virtuosos. En Místicos Franciscanos españoles, vol. II, Madrid, B.A.C., 1948, págs. 724-726.

31 PINELO, op. cit., fol. 77. 
"se reconocen así perpetuamente sujetas a los hombres»- y servía para "obligarlas a que sean y se muestren humildes»; y una matización: quienes las obligaban a cubrirse, con este acto mostraban su dominio. Ya lo recordaba el Catecismo de Trento al tratar de las obligaciones del marido: «Y los Padres enseñan que Eva fue formada del costado del hombre - no de los pies, ni aun siquiera de la cabeza-, para significar que no era señora, sino súbdita de su marido» ${ }^{32}$. Pero Pinelo iba más allá: el velo no era solamente prenda de casadas sino de todas las mujeres porque «lo natural del sexo en todas es la sujección", estar sujetas: "y así se verifica en las doncellas y viudas, porque todas están, y deben estar, sujetas al hombre» ${ }^{33}$.

Y la explicación: «El hombre tiene por gloria el ser imagen de Dios y la mujer el ser sujeta al hombre. El medio para que cada uno muestre que goza de esta gloria consiste en que el hombre descubra su rostro y la mujer lo cubra. Luego en el uso de los velos se halla la injuria y la afrenta del hombre, y la honra y alabanza de la mujer" ${ }^{34}$. Además de ser imagen de Dios, el hombre era la cabeza de la mujer en el matrimonio según lo había señalado San Pablo al comparar el marido a Cristo y la mujer con la Iglesia. Cristo era la cabeza de la Iglesia «y se entregó por ella, y la Iglesia está sujeta a Cristo", según su carta a los de Efeso.

A partir de lo dicho, dos particulares consideraciones sobre el uso del velo: una, que si el hombre es imagen y gloria de Dios, la mujer es gloria del hombre pero no su imagen por lo que debe cubrirse; y otra, que como por el matrimonio son dos en una carne, "dos cuerpos unidos a una cabeza», esta cabeza por lo dicho arriba es la del varón y por eso "así quiere el Apóstol, que la otra (cabeza) se cubra y no se vea».

Se explayaba Pinelo en su opinión sobre la mujer al justificar por qué el hombre, aparte de lo referido por San Pablo, era la cabeza y la mujer tenía que estar "sujeta». Primero, "porque es más perfecto, según el cuerpo y el vigor del alma». Segundo, "porque el varón naturalmente se aventaja y es superior a la mujer». Tercero, «porque gobernándose el hombre, queda y se entiende gobernada la mujer, en quien influye como en parte suya inferior; y así le ordenó Dios, que la señorease y tuviese en su poder y obediencia». Y cuarto: por prioridad de tiempo y origen en su creación. Así que, «la sujeción se muestra y significa en cubrirse el rostro. Luego la mujer le debe de cubrir» ${ }^{35}$.

Catecismo Romano. Madrid, B.A.C., 1956, págs. 676-677.

PINELO, op. cit., fol. $17 \mathrm{~V}$.

PINELO, op. cit., fol. 52.

PINELO, op. cit., fols. 52-52 v. 
No vamos a ir más allá. Si se observan los tres motivos aducidos por Pinelo, por los que la mujer debía cubrirse, se tiene que la sujeción era, al final, el eje alrededor del cual giraban los de autoridad y honestidad.

Después de todo, la mujer debía cubrir su rostro, que no ir «tapada» ya que en Portugal y en Castilla esto "se tiene por traje indecente y lascivo", porque era el "peligro" para la sociedad de hombres según los conductores de la sociedad barroca. «Fray Juan de la Puente dice que las mujeres pueblan la tierra de tiernos, el infierno de necios y el cielo de constantes. Unos porque las miran, otros porque en viéndolas luego las aman, y otros porque no las miran ni las ven para no amarlas». "Y así, pues la mujer es veneno, cubráse toda, como luego diremos, y por lo menos el rostro para que su vista no cause daños».

Y Pinelo añadía su particular queja a los responsables del Auto Acordado que, por entonces, prohibía el uso de guardainfantes y de jubones escotados y mandaba que las mujeres fueran descubiertas: «Y cuando tan justamente se ordena que se cubran los pechos y que se escondan los pies, mandar que se descubran los rostros, en que como dijo San Ambrosio "suele estar el riesgo y la tentación de la honestidad", no parece que tiene igual respeto» ${ }^{36}$.

Hemos elucubraclo y dado vueltas a un Tratado sobre la conveniencia o no del uso del velo por las mujeres en la Castilla del XVII. Al finalizar, acabaremos citando una frase del ya famoso Pinelo, para los lectores, que resumía la realidad de una sociedad contrarreformista prieta (en cuanto «negra») que permaneció durante siglos, y que provocó en sucesivas generaciones traumas y miedos y precaución en las básicas relaciones de hombres y mujeres: "el ver la mujer es malo, el oirla peor, y el tocarla malísimo. Porque lo uno incita, lo otro inflama y lo último entorpece» ${ }^{37}$.

36 PINELO, op. cit., fols. 79 v-80.

37 Pinelo, op. cit., fol. 77. 